\title{
KAJIAN POTENSI KULIT SAPI KERING SEBAGAI BAHAN DASAR PRODUKSI GELATIN HALAL
}

\section{POTENTIAL OF DRY COW SKIN AS A BASIC MATERIALS FOR HALAL GELATIN PRODUCTION}

\author{
Kirana Sanggrami Sasmitaloka*, Miskiyah, dan Juniawati \\ Balai Besar Litbang Pascapanen Pertanian, Bogor, 16114
}

Submitted: 11 January 2017, Accepted: 12 July 2017

\section{INTISARI}

Gelatin merupakan produk turunan protein yang diperoleh dari hidrolisis kolagen hewan yang dapat diekstraksi melalui proses asam dan basa. Pemanfaatan gelatin sudah sangat luas dan menjadi bagian dalam gaya hidup masyarakat Indonesia. Penelitian ini bertujuan untuk mengetahui sifat fisikokimia gelatin kulit sapi kering dibandingkan dengan sifat gelatin komersial yang distandarkan SNI. Penelitian didesain menggunakan rancangan acak lengkap pola searah dengan perlakuan jenis pelarut ekstraksi $\left(\mathrm{HCl} 1 \%, \mathrm{CH}_{3} \mathrm{COOH} 1 \%, \mathrm{NaOH} 1 \%\right)$ dengan ulangan sebanyak empat kali. Sebanyak $1000 \mathrm{~g}$ kulit sapi yang telah mengembang direndam dengan $\mathrm{HCl} 1 \%, \mathrm{CH}_{3} \mathrm{COOH} 1 \%$, dan $\mathrm{NaOH} 1 \%$ pada masing-masing wadah selama 4 hari $(1: 3(\mathrm{~b} / \mathrm{v}))$ kemudian dinetralkan, diekstraksi dengan air (1:3) menggunakan panci bertekanan $1 \mathrm{~atm}$ pada suhu $100^{\circ} \mathrm{C}$ selama 1 jam, didinginkan, disaring, dikeringkan, dan kemudian dihaluskan. Analisis produk gelatin meliputi rendemen, analisis proksimat, $\mathrm{pH}$, viskositas, kekuatan gel, dan kandungan logam (Cu, Zn, As, dan sulfit). Hasil analisis data dibandingkan dengan skor pada gelatin komersial dan SNI 06-3735-1995. Penggunaan pelarut asam dan basa untuk menghidrolisis kulit sapi kering menghasilkan gelatin dengan rendemen dan sifat fisikokimia yang berbeda nyata $(\mathrm{P}<0,05)$. Penggunaan $\mathrm{HCl} 1 \%$ sebagai larutan perendam dapat menghasilkan rendemen gelatin $65,75 \%$ lebih tinggi dibandingkan dengan perendaman $\mathrm{CH}_{3} \mathrm{COOH} 1 \%$ dan $27,71 \%$ lebih tinggi dibandingkan dengan perendaman $\mathrm{NaOH} 1 \%$. Gelatin yang dihidrolisis menggunakan pelarut $\mathrm{HCl} 1 \%$ menghasilkan gelatin dengan sifat fisikokimia yang sebagian besar memenuhi standar SNI dan gelatin komersial. Kesimpulan penelitian ini kulit sapi kering yang dihidrolisis menggunakan pelarut $\mathrm{HCl} 1 \%$ berpotensi sebagai alternatif bahan baku pembuatan gelatin.

(Kata kunci: Gelatin, Hidrolisis, Kulit sapi kering, Sifat fisikokimia, SNI Gelatin)

\section{ABSTRACT}

Gelatin is a protein product derived from the hydrolysis of animal tissues containing collagen through extraction process with acid or base treatment. The utilization of gelatin is very broad and has become part of the lifestyles of Indonesian. This research was conducted to study the physicochemical properties of dry cow skin gelatin compared to that commercial gelatin standardized by SNI. The experiment was set up in a one way completely randomized design with various kinds of solvent extraction $\left(\mathrm{HCl} 1 \%, \mathrm{CH}_{3} \mathrm{COOH} 1 \%, \mathrm{NaOH} 1 \%\right)$ and repeated four times. Sample $1000 \mathrm{~g}$ that has been soaked with $\mathrm{HCl} 1 \%, \mathrm{CH}_{3} \mathrm{COOH} 1 \%$, and $\mathrm{NaOH} 1 \%$ in each container for 4 days $(1: 3(w / v))$ then neutralized, extracted with water $(1: 3)$ using a $1 \mathrm{~atm}$ pressure pan at $100^{\circ} \mathrm{C}$ for 1 hour, cooled, filtered, dried, and crushed. The analysis of gelatin products includes rendement, proximate analysis, $\mathrm{pH}$, viscosity, gel strength, and metal content ( $\mathrm{Cu}, \mathrm{Zn}, \mathrm{As}$, and sulfite). Results of data analysis were compared with scores on commercial gelatin and SNI 06-3735-1995. The use of acid and alkali solvents to hydrolyze dry cow skin produce gelatin with a significantly different $(P<0.05)$ of yield and physicochemical properties. The utilization of $\mathrm{HCl} 1 \%$ as a submersion solution can result in yield product $65.75 \%$ higher than $\mathrm{CH}_{3} \mathrm{COOH} 1 \%$ immersions and $27.71 \%$ higher than $\mathrm{NaOH} 1 \%$ immersions. Hydrolysis gelatin using $\mathrm{HCl} 1 \%$ as a solvent produces gelatin with physicochemical properties almost matched to SNI and commercial gelatin standards. In conclusion, the dry cow skin wass hydrolyzed using $\mathrm{HCl} 1 \%$ potentially as an alternative raw material for gelatin production.

(Key words: Dry cow skin, Gelatin, Hydrolysis, Physicochemical properties, SNI of gelatin)

\footnotetext{
${ }^{*}$ Korespondensi (corresponding author):

Telp. +62 85643773752

E-mail: kirana.sanggrami@gmail.com
} 


\section{Pendahuluan}

Gelatin merupakan produk alami yang diperoleh melalui hidrolisis parsial kolagen dari kulit dan tulang hewan (Duconseille et al., 2015; Etxabide et al., 2015). Pemanfaatan gelatin sudah sangat luas. Diperkirakan sekitar $59 \%$ gelatin yang diproduksi di seluruh dunia digunakan untuk industri makanan, $31 \%$ pada industri farmasi, $2 \%$ pada industri fotografi, dan sekitar $8 \%$ diaplikasikan dalam industri lainnya (Mohebi dan Shahbazi, 2017).

Selama ini kebutuhan gelatin Indonesia diimpor dari beberapa negara seperti Perancis, Jepang, India, Brazil, Jerman, Cina, Argentina dan Australia (BPS, 2015). Impor gelatin pada tahun 2014 mencapai $255.822 \mathrm{~kg}$ dengan nilai US\$ 2.059.329 (BPS, 2015).

Salah satu aspek penting yang perlu diperhatikan adalah kehalalannya bagi umat muslim. Kuan et al. (2016) menyebutkan $98,5 \%$ gelatin di dunia diproduksi dari daging, tulang, dan kulit babi, oleh karena itu perlu dikembangkan produksi gelatin dari sumber hewan lain. Penelitian terdahulu telah menghasilkan teknologi produksi gelatin dari tulang sapi (Yuniarifin et al., 2006), tulang ikan (Marzuki et al., 2011), kulit ikan (Shyni et al., 2014), kulit ayam (Sarbon et al., 2013), kulit domba (Hasdar dan Rahmawati, 2017), kaki ayam (Rafieian et al., 2015), dan kaki bebek (Kuan et al., 2016).

Kulit sapi dapat digunakan sebagai alternatif bahan baku produksi gelatin. Kandungan kolagen dalam kulit mamalia sebesar 89\% (Hajrawati, 2006) dimana proporsi kulit dari seekor sapi mencapai 6,84 - 8,11 \% (Lestari et al., 2010). Apabila pada tahun 2015 terdapat 15,94 juta ekor sapi atau berat sekitar 506.661 ton sapi (Direktorat Jenderal Peternakan dan Kesehatan Hewan, 2016), maka dihasilkan 41.090 ton kulit sapi.

Pemanfaatan kulit sapi sebagai bahan baku gelatin telah banyak dikaji. Beberapa penelitian telah menggunakan kulit sapi hasil penyamakan (Nurhalimah, 2010; Sugihartono, 2014), kulit sapi dari rumah potong hewan (Nurhalimah, 2010), dan kulit sapi yang telah mengalami proses buang bulu (Youlanda, 2016) sebagai bahan baku gelatin, akan tetapi belum ada penelitian tentang pemanfaatan kulit sapi kering untuk pembuatan gelatin.
Teknik isolasi gelatin meliputi penggunaan pelarut asam, basa, dan enzim (Leuenberger, 1991). Produksi gelatin menggunakan hidrolisis enzim dapat menghasilkan gelatin dengan tingkat kemurnian yang tinggi, namun penggunaan enzim untuk hidrolisis memerlukan biaya yang mahal. Oleh karena itu, produksi gelatin dalam penelitian ini menggunakan hidrolisis asam dan basa dalam memproduksi gelatin, supaya teknologi ini dapat diterapkan di masyarakat.

Said et al. (2011) melaporkan bahwa gelatin kulit kambing yang dihidrolisis dengan $\mathrm{CH}_{3} \mathrm{COOH}$ menghasilkan rendemen 16,39\% dan kadar protein $90,74 \%$. Hasdar dan Rahmawati (2017) menghasilkan gelatin dari kulit domba menggunakan $\mathrm{NaOH}$ dengan rendemen $15,59 \%$ dan sifat yang mirip dengan gelatin komersial. Demikian pula dengan Nurhalimah (2010) yang mengekstrak gelatin dari kulit sapi split menggunakan $\mathrm{HCl}$ dengan sifat fisikokimia yang sesuai dengan SNI (SNI 1995).

Penelitian ini dilakukan untuk mengetahui sifat fisikokimia gelatin kulit sapi kering dibandingkan dengan sifat gelatin komersial yang distandarkan SNI. Produksi gelatin dilakukan melalui proses curing asam menggunakan pelarut $\mathrm{HCl}$ dan $\mathrm{CH}_{3} \mathrm{COOH}$ serta pelarut basa menggunakan $\mathrm{NaOH}$.

\section{Materi dan Metode}

Penelitian dilakukan di Laboratorium BB Pascapanen Balai Besar Litbang Pascapanen Pertanian, Kementerian Pertanian. Penelitian dilaksanakan pada bulan Juni - Oktober 2016.

Bahan utama yang digunakan adalah kulit sapi kering dari pabrik kulit Mirasa di Bantul, Yogyakarta. Sebagai pembanding, digunakan gelatin teknis Gelita (PT. Delisari Nusantara) dan gelatin Pro Analysis (PA) (Merck, nomor katalog 104078).

\section{Penghitungan kadar air}

Kadar air ditentukan menggunakan metode pengeringan dalam oven (SNI, 1992). Sebanyak $2 \mathrm{~g}$ sampel dipanaskan dalam oven suhu $105^{\circ} \mathrm{C}$ selama 5 jam, didinginkan dalam deksikator, dan ditimbang.

\section{Penghitungan kadar abu}

Kadar abu ditentukan menggunakan metode abu total (SNI, 1992). Sebanyak $2 \mathrm{~g}$ 
sampel diabukan dalam tanur pada suhu $550^{\circ} \mathrm{C}$ selama $5 \mathrm{jam}$.

\section{Penghitungan kadar protein}

Kadar protein ditentukan menggunakan metode semimikro Kjeldahl (SNI, 1992). Sebanyak $0,5 \mathrm{~g}$ sampel dimasukkan dalam labu Kjeldahl, ditambahkan $2 \mathrm{~g}$ campuran selen dan $12,5 \mathrm{ml} \mathrm{H}_{2} \mathrm{SO}_{4}$ pekat, dipanaskan sampai mendidih dan didinginkan pada suhu ruang. Larutan diencerkan dalam labu ukur $100 \mathrm{ml}$. Sebanyak $5 \mathrm{ml}$ larutan dipipet dan dimasukkan dalam alat penyuling, ditambahkan $5 \mathrm{ml} \mathrm{NaOH} \mathrm{30 \%} \mathrm{+} \mathrm{indikator} \mathrm{PP,}$ dan disuling selama 10 menit. Sebagai penampung, digunakan campuran $10 \mathrm{ml}$ larutan $\mathrm{H}_{3} \mathrm{BO}_{3} 2 \%$ + indikator Bromkresol hijau + Metil merah, selanjutnya dititrasi dengan $\mathrm{HCl} 0,1 \mathrm{~N}$ hingga terjadi perubahan warna menjadi merah muda.

\section{Penghitungan kadar lemak}

Kadar lemak ditentukan menggunakan metode ekstraksi langsung menggunakan Soxhlet (SNI, 1992). Sebanyak $2 \mathrm{~g}$ sampel dihidrolisis selama 15 menit dengan $30 \mathrm{ml}$ $\mathrm{HCl}$ dan $20 \mathrm{ml}$ aquades. Lemak yang tertampung disaring dan dioven dalam kertas saring pada suhu $70^{\circ} \mathrm{C}$ selama 3 jam. Setelah kering, dimasukkan ke dalam selongsong kertas dan diekstrak dengan heksana selama 3 jam. Hasil ekstraksi lemak dalam labu dikeringkan dengan oven pada suhu $105^{\circ} \mathrm{C}$, didinginkan pada suhu ruang dan ditimbang.

\section{Pembuatan gelatin kulit sapi}

Ekstraksi gelatin menggunakan metode Shyni et al. (2014) yang dimodifikasi, meliputi metode ekstraksi, penyaringan, dan pengeringan. Kulit sapi kering direndam dalam air (1:4) selama 1 hari. Sebanyak $1000 \mathrm{~g}$ kulit sapi yang mengembang direndam dengan $\mathrm{HCl} 1 \%, \mathrm{CH}_{3} \mathrm{COOH} 1 \%$, dan $\mathrm{NaOH} 1 \%$ pada masing-masing wadah selama 4 hari (1:3 (W/V)). Kemudian dinetralkan dengan air mengalir sampai $\mathrm{pH} 4$ - 6 dan diekstraksi dengan air (1:3) menggunakan panci bertekanan $1 \mathrm{~atm}$ pada suhu $100^{\circ} \mathrm{C}$ selama 1 jam. Hasil ekstraksi dipindahkan ke wadah stainless steel dan disimpan dalam lemari pendingin suhu $4^{\circ} \mathrm{C}$ selama 30 menit. Ada atau tidaknya gelatin terlihat dari endapan gelatin cair yang terbentuk. Ekstrak disaring menggunakan kain saring dan dikeringkan menggunakan metode penyangraian dengan teflon pada suhu $70^{\circ} \mathrm{C}$ selama 1 jam dan dihaluskan dengan blender.

\section{Penghitungan rendemen}

Rendemen diperoleh dari perbandingan berat kering gelatin yang dihasilkan dengan berat bahan segar (Alfaro et al., 2013).

\section{Pengukuran pH}

Larutan gelatin dibuat dalam konsentrasi $1 \%(\mathrm{~b} / \mathrm{v})$ menggunakan air destilasi pada suhu $60^{\circ} \mathrm{C}$, kemudian diaduk selama 30 menit dan didinginkan pada suhu ruang $\left(\sim 25^{\circ} \mathrm{C}\right)$ (Alfaro et al., 2013). pH diukur di Laboratorium Kimia BB Pascapanen.

\section{Pengukuran kelarutan}

Kelarutan diukur menggunakan metode Zhang et al. (2016). Sebanyak 6,67 g gelatin dilarutkan dalam $100 \mathrm{ml}$ air bersuhu $80^{\circ} \mathrm{C}$ dan diaduk. Pengamatan dilakukan secara visual. Jika tidak terbentuk endapan, maka gelatin tersebut dinyatakan larut dalam air suhu $80^{\circ} \mathrm{C}$.

\section{Pengukuran viskositas}

Viskositas gelatin diukur menggunakan metode Shyni et al. (2014) dengan modifikasi. Larutan gelatin konsentrasi $6,67 \%$ dipanaskan pada hot plate dengan suhu $80^{\circ} \mathrm{C}$ dan diaduk hingga larut. Sebanyak 20 $\mathrm{g}$ larutan diukur viskositasnya menggunakan Rapid Visco Analyzer (Perten) di Laboratorium Kimia BB Pascapanen.

\section{Pengukuran kekuatan gel}

Kekuatan gel diukur menggunakan metode Zhang et al. (2016). Larutan gelatin konsentrasi $6,67 \%$ dipanaskan pada hot plate dengan suhu $80^{\circ} \mathrm{C}$, diaduk hingga larut dan dimasukan ke gelas pengukuran. Selanjutnya disimpan pada suhu $10^{\circ} \mathrm{C}$ selama 18 jam. Pengukuran dilakukan menggunakan Texture Analyzer XT-21 (Brookfield) di Laboratorium Kimia BB Pascapanen.

\section{Penghitungan kandungan logam}

Analisis dilakukan terhadap logam $\mathrm{Cu}$, $\mathrm{Zn}$, As, dan Sulfit menggunakan metode dekstruksi (SNI, 1998). Sebanyak $2 \mathrm{~g}$ 
dimasukkan ke dalam oven $105^{\circ} \mathrm{C}$ selama 2 jam, selanjutnya diabukan dalam tanur suhu $550^{\circ} \mathrm{C}$ selama 6 jam. Sampel didekstruksi dengan penambahan $5 \mathrm{ml} \mathrm{HNO}_{3}$ pekat di atas penangas, kemudian dipekatkan menjadi 1-2 ml. Sampel didestruksi kembali dengan penambahan $5 \mathrm{ml} \mathrm{HCl} 6 \mathrm{~N}$ dan dipekatkan kembali. Larutan pekat diencerkan dalam labu takar $50 \mathrm{ml}$. Sampel dianalisis menggunakan Atomic Absorption Spectrometry (Shimadzu) di Labotrotirum Kimia BB Pascapanen.

\section{Analisis statistik}

Rancangan penelitian yang digunakan adalah rancangan acak lengkap dengan perlakuan bahan pelarut $(\mathrm{HCl} 1 \%$, $\mathrm{CH}_{3} \mathrm{COOH} 1 \%$, dan $\mathrm{NaOH} 1 \%$ ) dan diulang empat kali. Data yang diperoleh diolah menggunakan analisis sidik ragam (ANOVA) yang dilanjutkan dengan uji lanjut Duncan pada taraf nyata $5 \% \quad(\alpha=0,05)$ menggunakan paket program SPSS 21.0 Statistic Software. Hasil analisis data dibandingkan dengan skor pada Gelatin PA, gelatin teknis, dan SNI 06-3735-1995 tentang mutu dan cara uji gelatin.

\section{Hasil dan Pembahasan}

\section{Karakteristik bahan baku}

Bahan baku yang digunakan sebagai bahan baku gelatin pada umumnya, adalah kulit sapi samak dan kulit sapi yang langsung diambil dari RPH. Nurhalimah (2010) melaporkan bahwa kulit samak memiliki kadar air $60,77 \%$, kadar abu 5,46\%, kadar protein $55,10 \%$, dan kadar lemak $4,44 \%$. Sedangkan kulit dari RPH memiliki kadar air $59,07 \%$, kadar abu $5,14 \%$, kadar protein $47,73 \%$, dan kadar lemak 4,16\%.

Kulit sapi kering memiliki kadar air yang lebih rendah dibandingkan kulit samak dan kulit dari RPH (Tabel 1). Hal ini karena kulit sapi kering telah mengalami proses pengeringan, sehingga kandungan airnya sudah berkurang.
Kadar abu kulit sapi kering lebih rendah dibandingkan kulit samak dan kulit sapi dari RPH (Tabel 1). Kadar abu yang rendah menunjukkan kandungan mineral dalam kulit sapi kering yang rendah. Kandungan mineral akan berpengaruh pada kandungan logam pada produk gelatin yang dihasilkan.

Kadar lemak kulit sapi kering lebih rendah dibandingkan kadar lemak kulit hasil penyamakan dan kulit sapi dari RPH (Tabel 1). Kadar lemak yang rendah menunjukkan bahwa tidak perlu dilakukan penghilangan lemak sebelum proses perendaman.

Sebaliknya, kadar protein kulit sapi kering lebih tinggi dibandingkan kadar protein kulit samak dan kulit sapi dari RPH (Tabel 1). Hal ini menunjukkan kulit sapi kering berpotensi sebagai bahan baku gelatin dibandingkan kulit sapi hasil penyamakan dan kulit sapi dari RPH. Selain itu, penggunaan kulit sapi kering dapat menghemat waktu proses produksi gelatin, karena tidak memerlukan proses penghilangan lemak.

\section{Analisis sifat fisikokimia gelatin kulit sapi}

Rendemen. Hasil analisis statistik menunjukkan perlakuan jenis pelarut untuk menghidrolisis kulit sapi kering menghasilkan rendemen gelatin yang berbeda nyata $(\alpha<$ 0,05). Kołodziejska et al. (2008) menyebutkan semakin tinggi nilai rendemen maka semakin efisien proses produksi. Rendemen gelatin pada perendaman $\mathrm{HCl}$ $1 \%$ lebih tinggi $65,75 \%$ dibandingkan dengan perendaman $\mathrm{CH}_{3} \mathrm{COOH} 1 \%$ dan lebih tinggi $27,71 \%$ dibandingkan perendaman $\mathrm{NaOH}$ $1 \%$.

Peningkatan rendemen berkaitan dengan jumlah kolagen yang terkonversi menjadi gelatin. Penggunaan asam kuat menyebabkan peningkatan konsentrasi ion $\mathrm{H}^{+}$dalam larutan curing yang mempercepat proses hidrolisis. Laju hidrolisis yang semakin cepat cenderung meningkatkan konversi kolagen menjadi gelatin sehingga

Tabel 1. Analisis proksimat kulit sapi kering (proximate analysis of dry cow skin)

\begin{tabular}{llcc}
\hline \hline \multicolumn{1}{c}{ Parameters (parameters) } & $\begin{array}{c}\text { Kulit sapi kering } \\
(\text { dry cow skin) }\end{array}$ & $\begin{array}{c}\text { Kulit samak } \\
\text { (split leather) }^{*}\end{array}$ & $\begin{array}{c}\text { Kulit dari RPH } \\
\text { (slaughterhouse leather) }^{*}\end{array}$ \\
\hline Kadar air (\%) (moisture content (\%)) & $42,93 \pm 0,94$ & 60,77 & 59,07 \\
Kadar abu (\%) (ash content (\%)) & $0,17 \pm 0,02$ & 5,46 & 5,14 \\
Kadar protein (\%) (protein content $(\%))$ & $62,01 \pm 0,59$ & 55,10 & 47,73 \\
Kadar lemak (\%) (fat content (\%)) & $0,86 \pm 0,09$ & 4,44 & 4,16 \\
\hline
\end{tabular}

* Sumber: Nurhalimah (2010). 
Tabel 2. Rendemen gelatin kulit sapi kering

(yield of gelatin extracted from dry cow skin)

\begin{tabular}{|c|c|}
\hline Perlakuan (treatments) & Rendemen (yield) (\%) \\
\hline $\mathrm{HCl} 1 \%$ & $28,55 \pm 0,72^{a}$ \\
\hline $\mathrm{CH}_{3} \mathrm{COOH} 1 \%$ & $9,78 \pm 0,08^{b}$ \\
\hline $\mathrm{NaOH} 1 \%$ & $20,64 \pm 0,72^{c}$ \\
\hline
\end{tabular}

dapat meningkatkan nilai rendemen. Kołodziejska et al. (2008) menyebutkan apabila laju hidrolisis semakin besar maka pemecahan triple helix menjadi rantai $\alpha, \beta$ dan $Y$ juga semakin besar yang menyebabkan konversi gelatin semakin banyak.

Perendaman dengan larutan basa hanya menghasilkan rantai ganda (Yang et al., 2008). Pada waktu yang sama jumlah kolagen yang dihidrolisis oleh larutan asam lebih banyak daripada larutan basa. Sehingga pada waktu perendaman yang sama, rendemen gelatin menggunakan pelarut $\mathrm{HCl} 1 \%$ lebih besar dibandingkan pelarut $\mathrm{NaOH} 1 \%$.

Penggunaan asam lemah tidak meningkatkan ion $\mathrm{H}^{+}$dalam larutan curing, sehingga laju hidrolisis tidak meningkatkan jumlah konversi kolagen menjadi gelatin. Pelarut basa hanya menghasilkan rantai ganda, sehingga penggunaan basa kuat menyebabkan terjadinya peningkatan konsentrasi ion $\mathrm{OH}^{-}$yang mempercepat proses hidrolisis kolagen. Penggunaan $\mathrm{NaOH} 1 \%$ menghasilkan rendemen yang lebih besar $52,61 \%$ dibandingkan penggunaan $\mathrm{CH}_{3} \mathrm{COOH} 1 \%$.

$\mathrm{HCl}$ mampu menguraikan serat kolagen lebih banyak dan cepat tanpa mempengaruhi kualitas gelatin yang dihasilkan serta mengubah serat kolagen triple heliks menjadi rantai tunggal (Zhang et al., 2016). Hal ini sejalan dengan hasil penelitian Nurhalimah (2010) yang memproduksi gelatin menggunakan $\mathrm{HCl}$ sebagai larutan perendam dengan rendemen $22,12 \%$ (kulit samak) dan 26,12\% (kulit dari $\mathrm{RPH})$.

\section{Analisis proksimat}

Analisis proksimat dilakukan untuk mengetahui komponen dalam gelatin. Ninan et al. (2012) menyatakan air berperan dalam aktivitas metabolisme yang menimbulkan perubahan sifat organoleptik dan nilai gizi. Kadar air gelatin kulit sapi kering sesuai dengan SNI 06-3735-1995 (SNI 1995) dan lebih rendah dibandingkan gelatin komersial (teknis dan PA). Rendahnya kadar air gelatin yang dihasilkan dibandingkan dengan gelatin komersial (teknis dan PA) disebabkan kondisi penyimpanan gelatin komersial yang kurang baik ketika masih dalam toko. Sehingga meningkatkan kadar air gelatin komersial ketika diuji. Hasil analisis statistik menunjukkan bahwa penggunaan jenis pelarut menghasilkan kadar air gelatin yang berbeda nyata $(P<0,05)$. Hal ini menunjukkan penggunaan jenis pelarut dalam proses hidrolisis akan berpengaruh terhadap proses pengeringan gelatin.

Kadar abu dapat menunjukkan kemurnian produk. Hasil analisis statistik menunjukkan bahwa penggunaan jenis pelarut menghasilkan kadar abu gelatin yang berbeda nyata $(P<0,05)$. Kadar abu yang dihasilkan dari gelatin dengan pelarut asam sudah sesuai dengan SNI 06-3735-1995 (SNI, 1995). Sedangkan kadar abu pada perlakuan basa lebih tinggi dibanding kadar abu yang ditetapkan SNI 06-3735-1995 (SNI, 1995). Kadar abu yang tinggi disebabkan proses demineralisasi yang belum sempurna (Duconseille et al., 2015).

Gelatin diperoleh melalui proses hidrolisis kolagen, sehingga kadar protein gelatin lebih tinggi dari kadar protein kulit sapi kering (Tabel 3). Kadar protein gelatin yang dihasilkan lebih tinggi dari SNI $(87,62 \%)$. Hasil analisis statistik menunjukkan bahwa penggunaan jenis pelarut menghasilkan kadar protein gelatin yang berbeda nyata $(P<0,05)$, dimana kadar protein gelatin yang tertinggi diperoleh melalui hidrolisis menggunakan pelarut $\mathrm{HCl}$ $1 \%$. Hal ini menunjukkan bahwa pelarut $\mathrm{HCl}$ $1 \%$ mampu menghidrolisis kolagen dengan sempurna. $\mathrm{HCl}$ mampu menguraikan serat kolagen lebih banyak dan cepat tanpa mempengaruhi kualitas gelatin yang dihasilkan serta mengubah serat kolagen triple heliks menjadi rantai tunggal (Zhang et al., 2016). 
Kadar protein yang tinggi berkaitan langsung dengan sifat fisik gelatin seperti kekuatan gel dan viskositas. Gelatin yang memiliki kadar protein tinggi mengindikasikan bahwa gelatin tersebut memiliki mutu yang baik. Gelatin dengan kadar protein tinggi diharapkan dapat memberikan tambahan zat gizi terhadap produk pangan olahan selanjutnya.

Gelatin bermutu tinggi diharapkan memiliki kandungan lemak rendah bahkan tidak mengandung lemak. Kadar lemak gelatin yang diperoleh sesuai dengan SNI gelatin (SNI, 1995). Kadar lemak gelatin yang direndam $\mathrm{NaOH} 1 \%$ berbeda nyata dengan pelarut asam. Hal ini karena pelarut basa hanya bisa menghidrolisis triple helix menjadi double helix (Yang et al., 2008), sehingga tingkat exstruction lemak dalam sel belum optimal.

\section{$\mathrm{pH}$}

$\mathrm{pH}$ merupakan salah satu sifat kimia gelatin yang mempengaruhi aplikasi gelatin dalam produk. Gelatin $\mathrm{pH}$ netral diaplikasikan untuk produk daging, farmasi, kromatografi, cat dan sebagainya. Gelatin $\mathrm{pH}$ rendah digunakan untuk industri pangan sedangkan Gelatin $\mathrm{pH}$ tinggi diaplikasikan untuk industri farmasi.
$\mathrm{pH}$ gelatin berhubungan dengan proses ekstraksi yang digunakan Yang et al. (2008). Nilai pH yang dihasilkan tergantung pelarut yang digunakan pada saat perendaman untuk ekstraksi gelatin (Tabel 4). Proses asam menghasilkan $\mathrm{pH}$ rendah, sedangkan proses basa menghasilkan $\mathrm{pH}$ yang tinggi. Hasil analisis statistik menunjukkan bahwa penggunaan jenis pelarut menghasilkan $\mathrm{pH}$ gelatin yang berbeda nyata $(\alpha=0,05)$.

Perlakuan basa menghasilkan gelatin dengan $\mathrm{pH}$ basa. Hal ini disebabkan masih terdapat residu $\mathrm{NaOH}$ dalam gelatin yang dihasilkan. Ninan et al. (2012) menyatakan bahwa saat dilakukan proses perendaman, maka serabut kolagen kulit akan mengalami proses pembengkakan yang menyebabkan struktur ikatan asam amino pada molekul kolagen mengalami pembukaan dan pelarut "terperangkap" di antara ikatan tersebut dan tidak larut saat proses netralisasi.

$\mathrm{pH}$ gelatin kulit sapi kering yang dihasilkan menggunakan perlakuan $\mathrm{HCl} 1 \%$ dan $\mathrm{NaOH} 1 \%$ belum sesuai dengan standar $\mathrm{SNI}$, namun produk gelatin yang dihasilkan dapat diaplikasikan dalam industri pangan dan farmasi. Gelatin kulit sapi kering dengan perlakuan $\mathrm{HCl} 1 \%$ memiliki $\mathrm{pH}$ yang rendah, sehingga bersifat asam dan dapat

Tabel 3. Analisis proksimat gelatin kulit sapi kering (proximate analysis of gelatin extracted from dry cow skin)

\begin{tabular}{lcccc}
\hline \hline Perlakuan (treatments) & $\begin{array}{c}\text { Kadar air (\%) } \\
\text { (moisture content (\%)) }\end{array}$ & $\begin{array}{c}\text { Kadar abu (\%) } \\
(\text { ash content (\%)) }\end{array}$ & $\begin{array}{c}\text { Kadar lemak (\%) } \\
(\text { fat content (\%)) }\end{array}$ & $\begin{array}{c}\text { Kadar protein (\%) } \\
\text { (protein content (\%)) }\end{array}$ \\
\hline $\mathrm{HCl} \mathrm{1 \%}$ & $5,46 \pm 0,35^{\mathrm{a}}$ & $1,41 \pm 0,02^{\mathrm{a}}$ & $0,36 \pm 0,02^{\mathrm{a}}$ & $94,16 \pm 0,14^{\mathrm{a}}$ \\
$\mathrm{CH}{ }_{3} \mathrm{COOH} \mathrm{1 \%}$ & $8,71 \pm 0,97^{\mathrm{b}}$ & $0,46 \pm 0,09^{\mathrm{b}}$ & $0,37 \pm 0,07^{\mathrm{a}}$ & $88,63 \pm 0,55^{\mathrm{b}}$ \\
$\mathrm{NaOH} 1 \%$ & $3,08 \pm 0,21^{\mathrm{c}}$ & $6,04 \pm 0,58^{\mathrm{c}}$ & $0,78 \pm 0,05^{\mathrm{b}}$ & $92,71 \pm 0,67^{\mathrm{c}}$ \\
\hline $\begin{array}{l}\text { Gelatin PA (pro analysis } \\
\text { gelatin) }\end{array}$ & $12,54 \pm 0,15$ & $0,76 \pm 0,04$ & $0,26 \pm 0,04$ & $93,64 \pm 0,58$ \\
$\begin{array}{l}\text { Gelatin teknis (technical } \\
\text { gelatin) }\end{array}$ & $16,78 \pm 0,67$ & $1,56 \pm 0,03$ & $0,54 \pm 0,04$ & $89,40 \pm 0,42$ \\
$\begin{array}{l}\text { SNI gelatin (SNI of } \\
\text { gelatin) }\end{array}$ & Maks 16 & Maks 3,25 & $<5$ & 87,62 \\
$\begin{array}{l}\text { a,b,c,c Superskrip yang berbeda pada kolom yang sama menunjukkan perbedaan yang nyata (different supercript at the } \\
\text { same column indicate significant different). }\end{array}$
\end{tabular}

Tabel 4. pH gelatin kulit sapi kering ( $p H$ of gelatin extracted from dry cow skin)

\begin{tabular}{|c|c|}
\hline Perlakuan (treatments) & $\mathrm{pH}(\mathrm{pH})$ \\
\hline $\mathrm{HCl} 1 \%$ & $3,48 \pm 0,06^{a}$ \\
\hline $\mathrm{CH}_{3} \mathrm{COOH} 1 \%$ & $5,49 \pm 0,13^{b}$ \\
\hline $\mathrm{NaOH} 1 \%$ & $9,32 \pm 0,03^{c}$ \\
\hline Gelatin PA (pro analysis gelatin) & $5,11 \pm 0,01$ \\
\hline Gelatin teknis (technical gelatin) & $5,65 \pm 0,01$ \\
\hline SNI gelatin (SNI of gelatin) & $4,5-6,5$ \\
\hline
\end{tabular}


diaplikasikan untuk industri pangan. Gelatin kulit sapi kering dengan perlakuan $\mathrm{NaOH} 1 \%$ memiliki $\mathrm{pH}$ yang tinggi, sehingga bersifat basa dan dapat diaplikasikan untuk industri farmasi.

\section{Kelarutan}

Gelatin yang dihasilkan larut dalam air suhu $80^{\circ} \mathrm{C}$ (Tabel 5). Hal ini menunjukkan bahwa gelatin kulit sapi kering yang dihasilkan memiliki kualitas yang baik. Zhang et al. (2016) menyebutkan bahwa kategori gelatin kualitas baik bila diperoleh dari degradasi struktur triple helix protein kolagen kulit menjadi campuran polipetida yang bersifat mudah larut dalam air suhu $80^{\circ} \mathrm{C}$ dan bila suhu didinginkan akan membentuk gelatin.

\section{Viskositas}

Pengujian viskositas dilakukan untuk mengetahui tingkat kekentalan gelatin. Viskositas gelatin yang dihasilkan lebih tinggi daripada SNI dan gelatin komersial (Tabel 6). Hal ini menunjukkan kekentalan produk gelatin yang dihasilkan lebih tinggi dari gelatin komersial. Hastuti dan Sumpe (2007) menyatakan bahwa semakin besar nilai viskositas, maka semakin tinggi mutunya.

Gelatin dengan viskositas yang tinggi diperlukan untuk kestabilan emulsi gelatin. Karim dan Bhat (2009) menyebutkan bahwa viskositas gelatin yang tinggi menghasilkan laju pelelehan dan pembentukan gel yang lebih tinggi dibanding gelatin yang viskositasnya rendah.

Bahan curing dapat meningkatkan viskositas apabila mampu memecah ikatan peptide pada ikatan yang tepat dengan molekul yang lebih tinggi. Rafieian et al. (2015) menunjukkan bahwa rantai molekul yang panjang akan berpengaruh langsung terhadap nilai viskositas gelatin.

Viskositas gelatin yang tinggi dapat disebabkan oleh rendahnya kandungan abu pada gelatin kulit sapi kering. Tulang ikan Cucut dengan kadar abu 4,3\% menghasilkan viskositas 5,3 cP (Astawan and Aviana, 2003). Keberadaan mineral yang tergolong jenis abu dalam jumlah tertentu akan mempengaruhi viskositas, terutama jika mineral berasosiasi dengan gugus reaktif dari molekul gelatin, seperti gugus $\mathrm{OH}$, $\mathrm{COOH}$, dan $\mathrm{NH}_{2}$ (Duconseille et al., 2015).

\section{Kekuatan gel}

Kekuatan gel menunjukkan kemampuan gelatin untuk berubah dari fase gel menjadi sol dan sebaliknya. Hasil analisis statistik menunjukkan bahwa penggunaan jenis pelarut menghasilkan kekuatan gel gelatin yang berbeda nyata $(P<0,05)$. Kekuatan gel gelatin kulit sapi kering dengan perlakuan $\mathrm{CH}_{3} \mathrm{COOH} 1 \%$ masih di bawah kisaran nilai yang disyaratkan SNI. Gelatin pada penelitian ini, disaring dengan kain saring, sehingga pelarut terbawa dan

Tabel 5. Kelarutan gelatin kulit sapi kering

(solubility of gelatin extracted from dry cow skin)

\begin{tabular}{|c|c|}
\hline Perlakuan (treatments) & Kelarutan (solubility) \\
\hline $\mathrm{HCl} 1 \%$ & Larut (soluble) \\
\hline $\mathrm{CH}_{3} \mathrm{COOH} 1 \%$ & Larut (soluble) \\
\hline $\mathrm{NaOH} 1 \%$ & Larut (soluble) \\
\hline Gelatin PA (pro analysis gelatin) & Larut (soluble) \\
\hline $\begin{array}{l}\text { Gelatin teknis (technical gelatin) } \\
\text { SNI gelatin (SNI of gelatin) }\end{array}$ & $\begin{array}{l}\text { Larut (soluble) } \\
\text { Larut (soluble) }\end{array}$ \\
\hline
\end{tabular}

Tabel 6. Viskositas gelatin kulit sapi kering

(viscocity of gelatin extracted from dry cow skin)

\begin{tabular}{lc}
\hline \hline \multicolumn{1}{c}{ Perlakuan (treatments) } & Viskositas (viscosity) (cP) \\
\hline $\mathrm{HCl} 1 \%$ & $8,25 \pm 0,71^{\mathrm{a}}$ \\
$\mathrm{CH}_{3} \mathrm{COOH} 1 \%$ & $7,75 \pm 0,5^{\mathrm{a}}$ \\
$\mathrm{NaOH} \mathrm{1 \%}$ & $6,25 \pm 1,26^{\mathrm{b}}$ \\
\hline Gelatin PA (pro analysis gelatin) & $8,00 \pm 1,63$ \\
Gelatin teknis (technical gelatin) & $5,25 \pm 1,5$ \\
SNl gelatin (SNI of gelatin) & $1,5-7$ \\
\hline a,b,c Superskrip yang berbeda pada kolom yang sama menunjukkan perbedaan yang nyata (different supercript at the \\
\multicolumn{2}{l}{ same column indicate significant different). }
\end{tabular}


terperangkap dalam gelatin yang dapat meningkatkan bobot molekul gelatin.

Gelatin dengan molekul besar mempunyai rantai yang dihubungkan ikatan kovalen antar rantai yang dapat mengurangi jumlah ikatan hidrogen sehingga jaringan ikat antar molekul lemah dan kekuatan gel gelatin rendah (Shyni et al., 2014). Ikatan hidrogen antara molekul air bebas dan gugus hidroksil dari residu asam amino berperan penting dalam kekuatan gel.

Hafidz et al. (2011) menyebutkan bahwa gelatin kulit sapi mengandung prolin 63 per 1000 total residu asam amino, sedangkan gelatin kulit babi mengandung prolin 151 per 1000 total residu asam amino. Gelatin kulit babi memiliki kekuatan gel yang lebih besar dibandingkan gelatin kulit sapi.

Gelatin kulit sapi kering yang dihidrolisis menggunakan pelarut $\mathrm{HCl} 1 \%$ dan $\mathrm{NaOH} 1 \%$ memiliki kekuatan gel yang sesuai dengan persyaratan $\mathrm{SNI}$ dan lebih baik dari gelatin teknis. Kekuatan gel pada gelatin kulit sapi kering masih di bawah standar gelatin PA. Gelatin PA digunakan untuk analisis pada kegiatan penelitian, sehingga diperlukan tingkat kemurnian yang tinggi. Gelatin PA pada umumnya diproduksi melalui hidrolisis enzimatik. Yang et al. (2008) menyebutkan produksi gelatin menggunakan enzim dapat menghasilkan gelatin dengan tingkat kemurnian yang tinggi.

\section{Kandungan logam berat}

Hasil analisis statistik menunjukkan bahwa penggunaan jenis pelarut menghasilkan kadar protein gelatin yang tidak berbeda nyata $(\alpha=0,05)$. Hal ini menunjukkan bahwa penggunaan ketiga jenis pelarut dapat meminimalisir kandungan logam pada gelatin. Kandungan logam berat pada gelatin kulit sapi kering lebih rendah dari kandungan logam berat pada gelatin komersial dan persyaratan yang ditetapkan dalam SNI (Tabel 8). Hal ini menunjukkan bahwa gelatin kulit sapi kering yang dihasilkan memiliki kualitas yang bagus dan tingkat kemurnian yang tinggi.

Yuniarifin et al. (2006) menyebutkan bahwa kadar abu akan mempengaruhi kandungan mineral dalam produk yang dihasilkan. Semakin tinggi kadar abu, maka semakin tinggi kandungan mineral dalam produk. Hasil analisis proksimat menunjukkan gelatin kulit sapi kering memiliki kadar abu yang rendah (Tabel 1). Gelatin kulit sapi kering memiliki kandungan logam $\mathrm{Cu}, \mathrm{Zn}$, As, dan Sulfit yang rendah. Gelatin kulit sapi kering yang dihidrolisis menggunakan $\mathrm{NaOH} 1 \%$ memiliki kadar abu

Tabel 7. Kekuatan gel gelatin kulit sapi kering

(gel strength of gelatin extracted from dry cow skin)

\begin{tabular}{lc}
\hline \hline \multicolumn{1}{c}{ Perlakuan (treatments) } & Kekuatan gel (gel strength) (bloom) \\
\hline $\mathrm{HCl} 1 \%$ & $88,25 \pm 0,96^{\mathrm{a}}$ \\
$\mathrm{CH}_{3} \mathrm{COOH} 1 \%$ & $53,50 \pm 1,29^{\mathrm{b}}$ \\
$\mathrm{NaOH} \mathrm{1 \%}$ & $76,50 \pm 1,73^{\mathrm{c}}$ \\
\hline Gelatin PA (pro analysis gelatin) & $283 \pm 0,05$ \\
Gelatin teknis (technical gelatin) & $62 \pm 0,03$ \\
SNl gelatin (SNI of gelatin) & $75-3000$ \\
\hline a,b,c Superskrip yang berbeda pada kolom yang sama menunjukkan perbedaan yang nyata (different supercript at the \\
\multicolumn{2}{c}{ same column indicate significant different). }
\end{tabular}

Tabel 8. Kandungan logam berat pada gelatin kulit sapi kering

(heavy metal content of gelatin extracted from dry cow skin)

\begin{tabular}{|c|c|c|c|c|}
\hline Perlakuan (treatments) & $\begin{array}{c}\text { Kadar } \mathrm{Cu}(\mathrm{Cu} \\
\text { content) } \\
\text { (ppm) } \\
\end{array}$ & $\begin{array}{c}\text { Kadar Zn } \\
\text { (Zn content) } \\
(\mathrm{ppm}) \\
\end{array}$ & $\begin{array}{c}\text { Kadar As }(A s \\
\text { content) } \\
(\mathrm{ppm}) \\
\end{array}$ & $\begin{array}{c}\text { Kadar sulfit } \\
\text { (sulfit content) } \\
(\mathrm{ppm})\end{array}$ \\
\hline $\mathrm{HCl} 1 \%$ & $3,52 \pm 0,96^{a}$ & $12,45 \pm 0,95^{\mathrm{a}}$ & $0,005 \pm 0,0007^{a}$ & $0,00002 \pm 0,00000^{\mathrm{a}}$ \\
\hline $\mathrm{CH}_{3} \mathrm{COOH} 1 \%$ & $2,79 \pm 0,78^{a}$ & $10,43 \pm 0,96^{a}$ & $0,000 \pm 0,000^{b}$ & $0,00002 \pm 0,00000^{\mathrm{a}}$ \\
\hline $\mathrm{NaOH} 1 \%$ & $3,50 \pm 0,29^{a}$ & $12,78 \pm 0,61^{a}$ & $0,065 \pm 0,35^{a}$ & $0,00002 \pm 0,00000^{a}$ \\
\hline Gelatin PA (pro analysis gelatin) & $3,28 \pm 0,43$ & $12,46 \pm 1,18$ & Ttd & $4,3 \pm 0,00001$ \\
\hline Gelatin teknis (technical gelatin) & $5,61 \pm 0,28$ & $168,01 \pm 3,20$ & ttd- 0,04 & $12,075 \pm 0,00001$ \\
\hline SNI gelatin (SNI of gelatin) & Maks 30 & Maks 100 & Maks 2 & Maks 1000 \\
\hline
\end{tabular}


yang tinggi (Tabel 1). Gelatin ini memiliki kandungan logam $\mathrm{Zn}$ dan As yang tinggi pula (Tabel 8).

\section{Kesimpulan}

Penggunaan $\mathrm{HCl} 1 \%$ sebagai larutan perendam dapat menghasilkan rendemen gelatin $65,75 \%$ lebih tinggi dibandingkan dengan perendaman $\mathrm{CH}_{3} \mathrm{COOH} 1 \%$ dan $27,71 \%$ lebih tinggi dibandingkan dengan perendaman $\mathrm{NaOH} 1 \%$. Gelatin kulit sapi kering yang dihidrolisis $\mathrm{HCl} 1 \%$ memiliki sifat fisikokimia yang sebagian besar sesuai SNI dan lebih baik dari gelatin teknis komersial. Kulit sapi kering yang dihidrolisis menggunakan $\mathrm{HCl} 1 \%$ berpotensi sebagai alternatif bahan baku pembuatan gelatin.

\section{Daftar Pustaka}

Alfaro, A. D. T., G. G. Fonseca, E. Balbinot, A. Machado, and C. Prentice. 2013. Physical and chemical properties of wami tilapia skin gelatin. J. Food Sci. Technol. 33: 592-595.

Astawan, M. and T. Aviana. 2003. Pengaruh jenis larutan perendam serta metode pengeringan terhadap sifat fisik, kimia, dan fungsional gelatin dari kulit cucut. J. Teknol dan Industri Pangan. 17: 713.

BPS. 2015. Statistik Perdagangan Luar Negeri. Maret 2015. Vol. 3842508. Jakarta: Badan Pusat Statistik. http://www.bps.go.id. Diakses pada 2 Mei 2017.

Direktorat Jenderal Peternakan dan Kesehatan Hewan. 2016. Populasi Peternakan di Indonesia. Kementerian Pertanian.

http: //aplikasi.pertanian.go.id/bdsp/hasil ko m.asp. Diakses pada 2 Mei 2017.

Duconseille, A., T. Astruc, N. Quintana, F. Meersman, and V. E. SanteLhoutellier. 2015. Gelatin structure and composition linked to hard capsule dissolution: A review. J. Food Hydrocoll. 43: 360-376.

Etxabide, A., M. Urdanpilleta, P. Guerrero, and K. de la Caba. 2015. Effects of crosslinking in nanostructure and physicochemical properties of fish gelatins for bioapplications. J. Reactive and Functional Polymers. 94: 55-62.

Hafidz, R. M. R. N., C. M. Yaakob, I. Amin, and A. Noorfaizan. 2011. Chemical and functional properties of bovine and porcine skin gelatin. J. Int. Food. Res. 18: 813-817.

Hajrawati. 2006. Sifat Fisik dan kimia gelatin tulang sapi dengan perendaman asam klorida pada konsentrasi dan lama perendaman yang berbeda. Tesis Sekolah Pascasarjana, Institut Pertanian Bogor, Bogor.

Hasdar, M. and Y. D. Rahmawati. 2017. Kajian potensi kulit domba asal Brebes sebagai bahan dasar produksi gelatin halal. Jurnal Aplikasi Teknologi Pangan. 6: 1-6.

Hastuti, D. and I. Sumpe. 2007. Pengenalan dan proses pembuatan gelatin. Jurnal IImu-IImu Pertanian. 3: 39-48.

Karim, A. A. and R. Bhat. 2009. Fish gelatin: properties, challenges, and prospects as an alternative to mammalian gelatins. J. Food Hydrocoll. 23: 563 576.

Kołodziejska, I., E. Skierka, M. Sadowska, W. Kołodziejski, and C. Niecikowska. 2008. Effect of extracting time and temperature on yield of gelatin from different fish offal. J. Food Chem. 107: 700-706.

Kuan, Y. H., A. M. Nafchi, N. Huda, F. Ariffin, and A. A. Karim. 2016. Effects of sugars on the gelation kinetics and texture of duck feet gelatin. J. Food Hydrocoll. 58: 267-275.

Lestari, C. M. S., Y. Hudoyo, and S. Dartosukarno. 2010. Proporsi karkas dan komponen - komponen nonkarkas sapi Jawa di Rumah Potong Hewan swasta Kecamatan Ketanggungan Kabupaten Brebes. Prosiding Seminar Nasional Teknologi Peternakan dan Veteriner, 3 - 4 Agustus 2010, Balai Penelitian Ternak, Bogor.

Leuenberger, B. H. 1991. Investigation of viscosity and gelation properties of different mammalian and fish gelatins. J. Food Hydrocoll. 5: 353-361.

Marzuki, A., E. Pakki, and F. Zulfikar. 2011. Ekstraksi dan penggunaan gelatin dari limbah tulang ikan bandeng (Chanos Chanos Forskal) sebagai emulgator dalam formulasi sediaan emulsi. Majalah Farmasi dan Farmakologi. 15: 63-68.

Mohebi, E. and Y. Shahbazi. 2017. Application of chitosan and gelatin 
based active packaging films for peeled shrimp preservation: A novel functional wrapping design. J. Food Sci. Technol. 76: 108-116.

Ninan, G., J. Joseph, and Z. A. Aliyamveettil. 2012. A comparative study on the physical, chemical and functional properties of carp skin and mammalian gelatins. J. Food Sci. Technol. 51: 2085-2091.

Nurhalimah, E. 2010. Perbandingan ekstraksi gelatin kulit sapi split dengan proses asam dan basa. Skripsi Fakultas Matematika dan IImu Pengetahuan, Institut Pertanian Bogor, Bogor.

Rafieian, F., J. Keramat, and M. Shahedi. 2015. Physicochemical properties of gelatin extracted from chicken deboner residue. J. Food Acien. Technol. 64: 1370-1375.

Said, M. I., J. C. Likadja, dan M. Hatta. 2011. pengaruh waktu dan konsentrasi bahan curing terhadap kuantitas dan kualitas gelatin kulit kambing yang diproduksi melalui proses asam. Jurnal Ilmu dan Teknologi Pangan 1: 119128.

Sarbon, N. M., B. Farah, and K. H. Nazlin. 2013. Preparation and characterisation of chicken skin gelatin as an alternative to mammalian gelatin. $\mathrm{J}$. Food Hydrocoll. 30: 143-151.

Shyni, K., G. S. Hema, G. Ninan, S. Mathew, C. G. Joshy, and P. T. Lakshmanan. 2014. Isolation and characterization of gelatin from the skins of skipjack tuna (Katsuwonus Pelamis), dog shark (Scoliodon Sorrakowah), and rohu (Labeo Rohita). J. Food Hydrocoll. 39: 68-76.

SNI. 1992. Cara uji makanan dan minuman. SNI 01-289. Badan Standarisasi Nasional, Jakarta.
SNI. 1995. Mutu dan cara uji gelatin. SNI 06373. Badan Pusat Statistik, Jakarta.

SNI. 1998. Cara uji cemaran logam dalam makanan. SNI 19-289. Badan Standarisasi Nasional, Jakarta. http:// sertifikasibbia.com/upload/logam_bera t.pdf.

Sugihartono. 2014. Kajian gelatin dari kulit sapi limbah sebagai renewable flocculants untuk proses pengolahan air. J. Industrial Res. 8: 179-190.

Yang, H., Y. Wang, P. Zhou, and J. M. Regenstein. 2008. Effects of alkaline and acid pretreatment on the physical properties and nanostructures of the gelatin from channel catfish Skins. J. Food Hydrocoll. 22: 1541-1550.

Youlanda, H. 2016. Ekstraksi dan evaluasi gelatin dari kulit sapi yang telah mengalami proses buang bulu menggunakan hidrolisis asam. Skripsi Fakultas Kedokteran dan IImu Kesehatan, UIN Syarif Hidayatullah, Jakarta

Yuniarifin, H., V. P. Bintoro, dan A. Suwarastuti. 2006. Pengaruh berbagai konsentrasi asam fosfat pada proses perendaman tulang sapi terhadap rendemen, kadar abu dan viskositas gelatin. J. Indonesian Trop. Anim. Agric. 31: 55-61.

Zhang, Q., Q. Wang, S. Lv, J. Lu, S. Jiang, J. M. Regenstein, and L. Lin. 2016. Comparison of collagen and gelatin extracted from the skins of nile tilapia (Oreochromis Niloticus) and channel catfish (Ictalurus Punctatus). J. Food Biosci. 13: 41-48. 